\title{
Comparative study of the anti-inflammatory, antioxidant and urease inhibitory activities of Eryngium kotschyi Boiss. and $E$. campestre L. var. virens (Link) Weins extracts
}

\author{
İrem ATAY BALKAN 1 * (D) , Turgut TAŞKIN 2 (D), Esra ACAR ŞAH ${ }^{3}$ (D), Galip AKAYDIN 4 (D), \\ Erdem YEŞILAADA 5 (iD)
}

1 Department of Pharmacognosy, Hamidiye Faculty of Pharmacy, University of Health Sciences Turkey, Üsküdar 34668 İstanbul, Turkey.

2 Department of Pharmacognosy, Faculty of Pharmacy, Marmara University, Haydarpasa 34668 İstanbul, Turkey.

3 Department of Pharmacognosy, School of Pharmacy, İstanbul Medipol University, Beykoz 34810 İstanbul, Turkey.

4 Department of Biology Education, Hacettepe University, Beytepe 06800 Ankara, Turkey

5 Department of Pharmacognosy, Faculty of Pharmacy, Yeditepe University, Ataşehir 34755 İstanbul, Turkey.

* Corresponding Author. E-mail: irematay@yahoo.com (İ.A.); Tel. +90-216-418 96 16/28 04.

Received: 16 December 2019 / Revised: 07 April 2020/ Accepted: 13 April 2020

\begin{abstract}
Despite widespread traditional usage of Eryngium species in Anatolia (Turkey), only a limited number of scientific studies exists on E. kotschyi, an endemic species. Previously, extracts from E. campestre and E. kotschyi were reported to have significant anti-inflammatory effects in vivo. This study aimed to investigate the in vitro antiinflammatory, antioxidant, urease inhibitory activities of ethanol extracts of $E$. kotschyi and E. campestre var. virens roots as well as distilled water and ethanol extracts of E. kotschyi aerial parts. The $\mathrm{NO}$ and cytokine inhibitory effects were evaluated by Griess and ELISA assays. The antioxidant activities were tested on DPPH ${ }^{\circ}$, ABTS ${ }^{\bullet+}$ and CUPRAC assays. The EtOH extract of E. kotschyi roots (EKr EtOH) and aerial parts (EKae EtOH) inhibited 50.08\% and $41.52 \%$ of NO production at $100 \mu \mathrm{g} / \mathrm{ml}$, respectively. The EtOH extract of the roots of E. campestre var. virens (ECr EtOH) and EKr EtOH provided $36.22 \%$ and $65.23 \%$ IL-6 inhibition and $44.24 \%$ and $56.84 \%$ IL-1a inhibition at $100 \mu \mathrm{g} / \mathrm{ml}$. EKae EtOH exerted highest antioxidant activity on ABTS $\bullet+(2.4 \pm 0.0005 \mu \mathrm{M}$ trolox $/ \mathrm{mg}$ extract) and CUPRAC $(0.97 \pm 0.07 \mathrm{mM}$ trolox/mg extract). This extract was also found the richest among all in terms of phenolics content $(6.1 \pm 0.001$ $\mathrm{mg} / \mathrm{GAE} / \mathrm{g}$ extract). EKr EtOH and ECr EtOH exhibited strongest $\mathrm{DPPH}^{\bullet}\left(\mathrm{IC}_{50}=1.132 \pm 0.057 \mathrm{mg} / \mathrm{ml}\right) \mathrm{radical}$ scavenging and ferric reducing/antioxidant power $(0.36 \pm 0.005 \mathrm{mM}$ Fe2+/mg extract) activity respectively. The extracts exerted low urease inhibitory activity. Consequently, the results of this study might contribute to the elucidation of the mechanism of in vivo anti-inflammatory activity of the extracts.
\end{abstract}

KEYWORDS: Eryngium kotschyi; Eryngium campestre var. virens; anti-inflammatory; antioxidant; urease inhibition, phenolics.

\section{INTRODUCTION}

Eryngium (Apiaceae) species are known as 'boğadikeni' in Anatolia and represented by 25 species (1). Eryngium kotschyi Boiss., which is one of the endemic Eryngium species of Turkey, is a perennial plant which has amethyst colored, dense paniculate flowers [2,3]. Eryngium species are traditionally used for a broad spectrum of diseases in Anatolia; notably roots are used for inflammatory diseases such as sinusitis, urinary infections, oedema or inflammations $[4,5]$.

Results of a literature survey showed that there are only a limited number of studies on $E$. kotschyi except of the studies that report cytotoxic, in vivo antinociceptive and anti-inflammatory activities of the plant $[3,6$, 7]. On the other hand, Eryngium campestre L. var. virens (Link) Weins is a perennial plant which is usually about 30-60 cm in length. Cytotoxic, antibacterial, antitumor, anti-inflammatory and antinociceptive activities were previously reported for $E$. campestre $[3,8,9,10]$. Triterpen saponins, flavonoids and coumarins were previously isolated from $E$. campestre while triterpene saponins were isolated from $E$. kotschyi $[6,11,12,13,14,15,16]$. In a previous work, the ethanol $(\mathrm{EtOH})$ extract of the roots of $E$. kotschyi and E. campestre as well as $\mathrm{dH}_{2} \mathrm{O}$ and $\mathrm{EtOH}$ extracts of the aerial parts of E. kotschyi exerted significant anti-inflammatory effects on carrageenan induced oedema model [3].

How to cite this article: Atay Balkan I, Taşkın T, Acar Şah E, Akaydın G, Yeşilada E. Comparative study of the anti-inflammatory, antioxidant and urease inhibitory activities of Eryngium kotschyi Boiss. and E. campestre L. var. virens (Link) Weins extracts. J Res Pharm. 2020; $24(3)$ : 399-409. 
Inflammation occurs as a defense mechanism of the body against various destructive stimuli (chemical, biological or physical), however when it becomes persistent as chronical inflammation, it contributes to the progression of many diseases. These diseases include inflammatory bowel diseases, neurodegenerative disorders, rheumatoid arthritis, heart attacks, Alzheimer's disease, and cancers [17, 18, 19]. Although inflammatory responses manifest itself in distinct ways among various inflammatory diseases, they can all be characterised by common mediators including prostaglandins, chemokines, inflammatory cytokines, and toxic molecules such as nitric oxide and free radicals $[17,18]$. Among them nitric oxide (NO) is produced by many cell types in the body as a crucial mediator involving in critical physiological functions such as the regulation of vascular tone, neurotransmission and immune system, while in high concentrations NO and its reactive derivatives such as peroxynitrite involves in the pathogenesis of inflammation, sepsis and carcinogenesis [20]. Therefore, inhibition of NO production is endorsed to be an important measure to asses the activity of possible drug candidates against inflammation [21]. Likewise, cytokines are also of important value which are divided into two subgroups depending on their ability to induce or reduce inflammation; proinflammatory and anti-inflammatory cytokines, succesfully. Interleukin (IL)- 1 and IL-6 which are classified as proinflammatory cytokines, involve in processes such as inflammation, tissue destruction and shock, and induce the transcription of proinflammatory genes [22, 23]. It was shown that IL-6 levels are raised in many inflammatory diseases such as systemic lupus erythematosus, psoriasis, rheumatoid arthritis, Crohn's disease, systemic juvenile idiopathic arthritis and ankylosing spondylitis [24].

Oxidative stress occurs when the antioxidant defence mechanisms of the body failes to balance the effects of reactive oxygen species (ROS). The progression of various diseases including inflammatory diseases, cancer and diabetes is found to be associated with oxidative stress [25]. Researches indicate that oxydative stress is induced by inflammatory process or vice versa and reduces cellular antioxidant capacity [26].

Helicobacter pylori is a major cause of chronic inflammation of stomach. Peptic ulcer and neoplastic processes on gastric mucosa have been shown to be related with the activity of the pathogens in stomach. Urease activity of $H$. pylori allows it to survive in the acidic condition of stomach. The pathogen's urease pathway have been widely targeted by drug discovery studies [27].

In order to further elucidate the previously reported mechanism on the in vivo anti-inflammatory activity of the extracts from the roots and aerial parts of E. kotschyi, the present study was designed to investigate the in vitro anti-inflammatory and antioxidant potentials of these extracts. The in vitro antiinflammatory and antioxidant activities of the root extract of E. campestre var. virens was also studied. Moreover, to obtain an opinion on the potential benefits of these extracts against Helicobacter pylori infection their urease inhibitory activities were studied. The antioxidant activities and the phenolic contents of the plant extracts were repeatedly shown to be correlated. The phenolic compounds are known to be strong antioxidants [28]. For that reason, the chemical compositions of the extracts were also compared based on their total phenolic contents.

\section{RESULTS}

\subsection{Total phenolic contents}

The highest total phenolic content was determined in EKae EtOH $(6.1 \pm 0.001 \mathrm{mgGAE} / \mathrm{g}$ extract). The total phenolic contents of EKae $\mathrm{dH}_{2} \mathrm{O}(3.4 \pm 0.002 \mathrm{mg} \mathrm{GAE} / \mathrm{g}$ extract) and $\mathrm{EKr} \mathrm{EtOH}(3.1 \pm 0.004 \mathrm{mgGAE} / \mathrm{g}$ extract) were found to be close. On the other hand, $\mathrm{ECr} \mathrm{EtOH}(0.2 \pm 0.05 \mathrm{mg} \mathrm{GAE} / \mathrm{g}$ extract) was found to contain the lowest levels of phenolics.

\subsection{Effects of the extracts on cell viability}

The non-toxic concentrations of the extracts on Raw 264.7 macrophages were determined by WST-1 assay (Figure 1). The indicated concentrations $(12.5,25,50$ and $100 \mu \mathrm{g} / \mathrm{ml}$ ) of extracts with lipopolysachharides (LPS, $1 \mu \mathrm{g} / \mathrm{ml}$ ) were applied to cells, and incubated at $37^{\circ} \mathrm{C}$ for $24 \mathrm{~h}$. The viability of the cells were not significantly decreased by the treatment with the EtOH extract of the aerial parts of E. kotschyi [EKae EtOH] (Figure 1A). On the other hand, the $\mathrm{dH}_{2} \mathrm{O}$ extract of the aerial parts of the same plant [EKae $\mathrm{dH}_{2} \mathrm{O}$ ] applied at the same concentration slightly reduced the cellular viability of the cells at the highest two concentrations (Figure 1C). The cell viabilities were $85.70 \pm 4.21 \%$ and $80.65 \pm 7.42 \%$ at 50 and $100 \mu \mathrm{g} / \mathrm{ml}$ concentrations, respectively. The $\mathrm{EtOH}$ extract of the roots of E. kotschyi $[\mathrm{EKr} \mathrm{EtOH}]$ only slightly decreased the cell viability $(80.96 \pm 3.60 \%)$ at $100 \mu \mathrm{g} / \mathrm{ml}$ concentration (Figure 1B). The EtOH extract of the roots of E. campestre var. virens [ECr EtOH] did not significantly decreased cellular viability (Figure 1D). L-N6-(1-iminoethyl) lysine (L-NIL) at $10 \mu \mathrm{M}$ did not significantly reduce the viability of Raw 264.7 cells. 
(A)

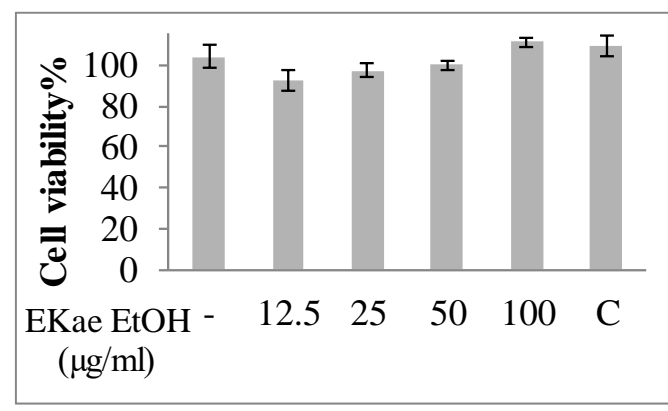

(C)

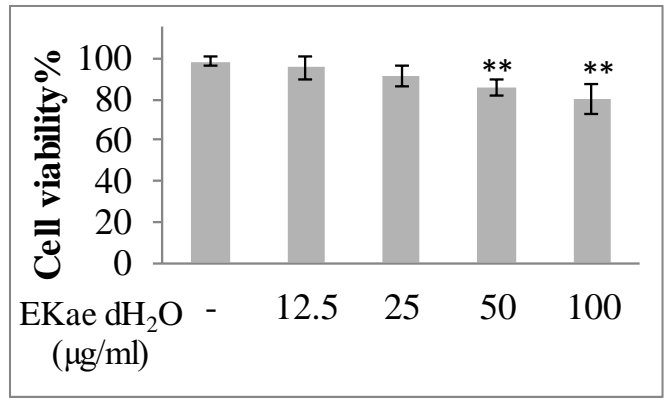

(B)

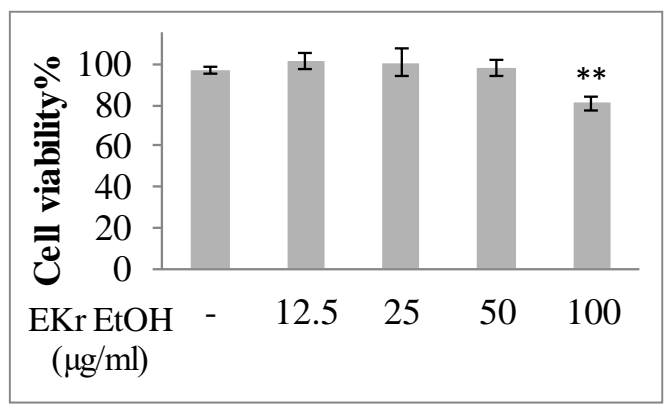

(D)

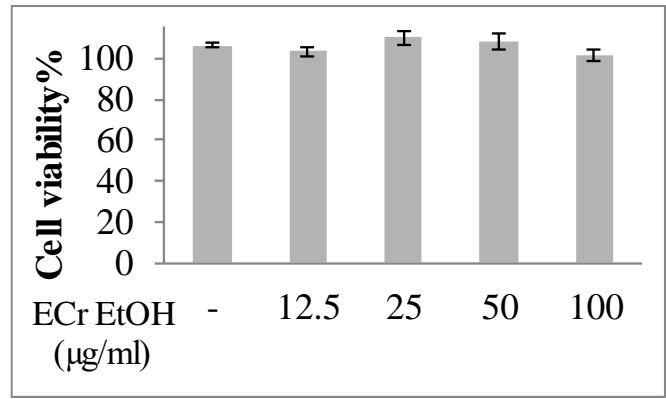

Figure 1. Effects of E. kotschyi extracts [aerial $\mathrm{EtOH}(\mathrm{A})$, root $\mathrm{EtOH}(\mathrm{B})$, aerial $\mathrm{dH}_{2} \mathrm{O}(\mathrm{C})$ ] and E. campestre var. virens root EtOH extract (D) on the viability of Raw 264.7 macrophages as determined by WST-1 assay. Indicated concentrations of extracts were applied to cells with LPS $(1 \mu \mathrm{g} / \mathrm{ml})$ for $24 \mathrm{~h}$. C: L-NIL applied at $10 \mu \mathrm{M}$ concentration. (-): Only media treated control group. Error bars represents the mean \pm SEM value for three experiments. Values of ${ }^{*} p \leq 0.05,{ }^{* *} p \leq 0.01$ and ${ }^{* * *} p \leq 0.001$ were considered statistically significant compared to only media treated control group.

\subsection{Effects of the extracts on NO production}

Raw 264.7 cells were co-incubated with the indicated concentrations $(12.5,25,50$ and $100 \mu \mathrm{g} / \mathrm{ml})$ of the extracts and LPS $(1 \mu \mathrm{g} / \mathrm{ml})$ for $24 \mathrm{~h}$ to determine the NO inhibitory activities. As shown in Figure 2, the treatment of cells with LPS resulted in a significant increasement of NO levels compared to only media treated control group. Although EKae $\mathrm{dH}_{2} \mathrm{O}$ (Figure 1C) and $\mathrm{ECr}$ EtOH (Figure 1D) did not exert remarkable inhibition at these concentrations, the other two extracts exerted significant inhibitions. EKr EtOH inhibited $4.31 \%, 12.47 \%, 19.62 \%$ and $50.08 \%$ of NO production at $12.5,25,50$ and $100 \mu \mathrm{g} / \mathrm{ml}$ concentrations respectively. On the other hand, EKae EtOH inhibited 13.85\%, 24.61\%, 33.44\%, 41.52\% of NO production at the same concentrations. It is noteworthy that despite the fact that $\mathrm{EKr} \mathrm{EtOH}$ was found to be more active at high concentration $(100 \mu \mathrm{g} / \mathrm{ml})$, the activities of EKae EtOH was found to be higher at lower concentrations. L-NIL which is a known inhibitor of NO, exerted $86.94 \%$ inihibition at $10 \mu \mathrm{M}$ concentration.

\subsection{Effects of the extracts on the production of IL-6 and IL-1a on LPS-induced Raw 264.7 macrophages}

Raw 264.7 macrophages were co-incubated with both LPS $(1 \mu \mathrm{g} / \mathrm{ml})$ and the indicated concentrations $(12.5,50$ and $100 \mu \mathrm{g} / \mathrm{ml})$ of the extracts and for $24 \mathrm{~h}$. After that the media was collected and IL-6 levels were measured. As shown in Figure 3 the treatment of cells with LPS significantly increased IL-6 levels compared to only media treated control group. ECr EtOH inhibited 11.05\%, 18.10\%, 36.22\% of IL-6 production at these concentrations (Figure 3D). EKr EtOH exerted remarkable inhibition (65.23\%) only at the highest concentration

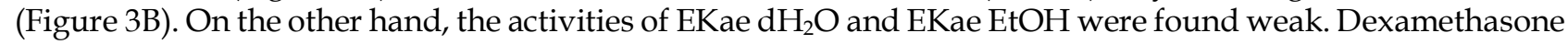
which is a known inhibitor of IL-6 production, exerted $80.14 \%$ inihibition at $5 \mu \mathrm{M}$ concentration.

All extracts were tested for their IL-1a inhibitory potentials at $100 \mu \mathrm{g} / \mathrm{ml}$ concentrations. EKae $\mathrm{dH}_{2} \mathrm{O}$ and EKae EtOH did not significantly inhibit IL-1a productions. EKr EtOH significantly inhibited IL-1a in a concentration dependent manner. This extract provided $38.94 \%$ and $56.84 \%$ decrease in IL-1a levels at 50 and $100 \mu \mathrm{g} / \mathrm{ml}$ concentraions compared to only LPS treated control group (Figure $4 \mathrm{~B}$ ). ECr EtOH inhibited 50.92\%, $44.24 \%$ of IL-1a production at these concentrations (Figure 4C). 
(A)

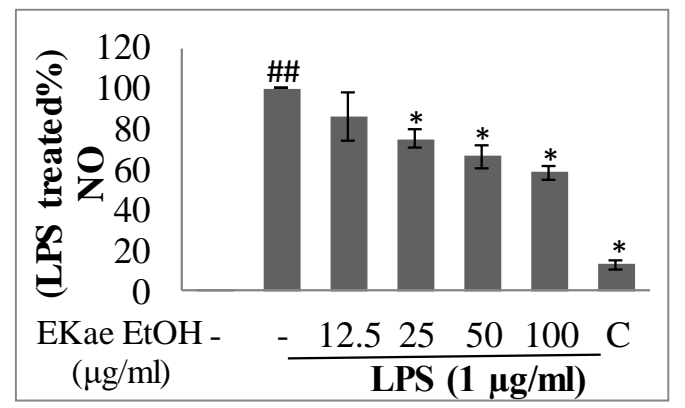

(C)

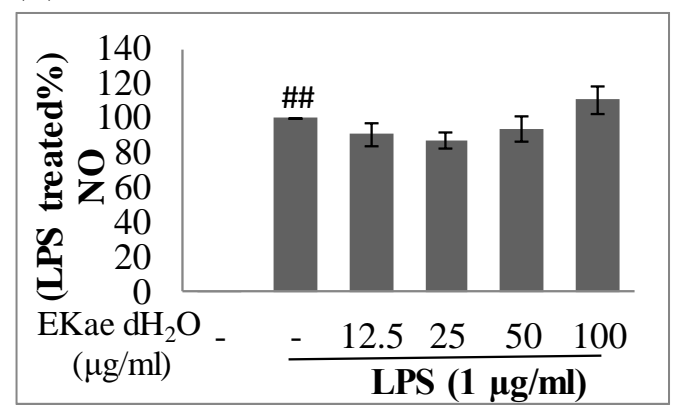

(B)

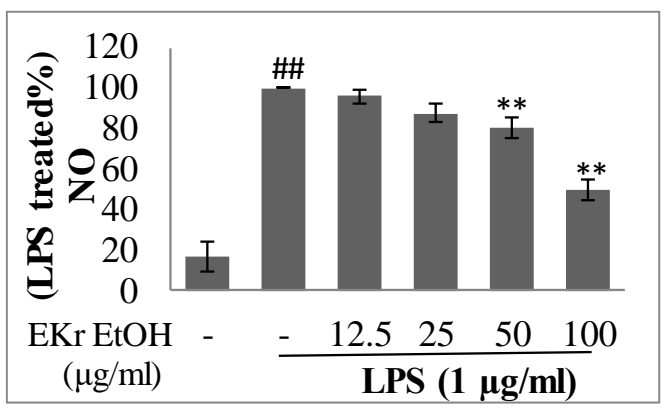

(D)

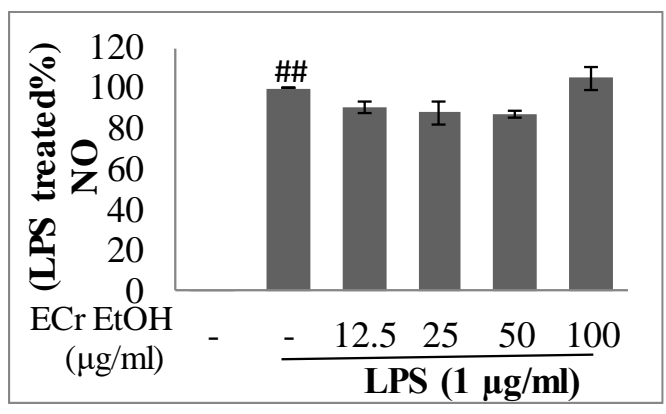

Figure 2. Effect of E. kotschyi extracts [aerial EtOH (A), root EtOH (B), aerial $\mathrm{dH}_{2} \mathrm{O}(\mathrm{C})$ ] and E. campestre var. virens root EtOH extract (D) on the NO productions of LPS induced Raw 264.7 macrophages as determined by Griess Assay. The indicated concentrations of extracts was co-incubated with LPS $(1 \mu \mathrm{g} / \mathrm{ml})$ for $24 \mathrm{~h}$. C: L-NIL $(10 \mu \mathrm{M})$ was applied. (-): Only media treated control group. Error bars represents the mean \pm SEM values for three experiments. Values of ${ }^{*} p \leq 0.05,{ }^{* *} p \leq 0.01$ and ${ }^{* * *} p \leq 0.001$ vs. LPS treated control group and \# $\mathrm{p} \leq 0.05$, \#\# $\mathrm{p} \leq 0.01$ and \#\#\# $\mathrm{p} \leq 0.001$ vs. only media treated group were considered statistically significant.

(A)

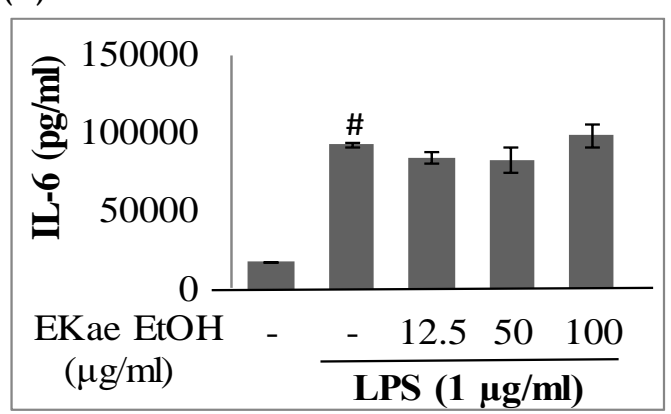

(C)

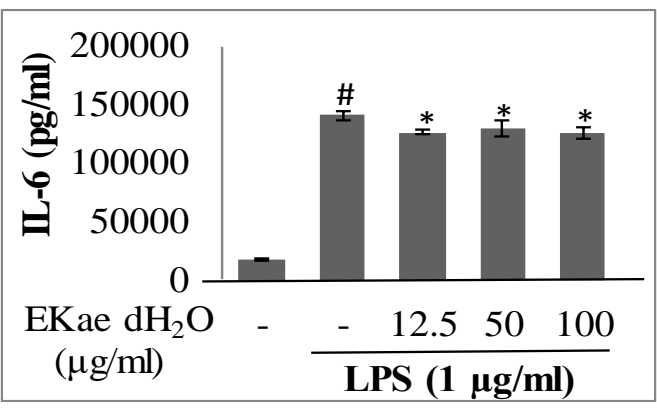

(B)

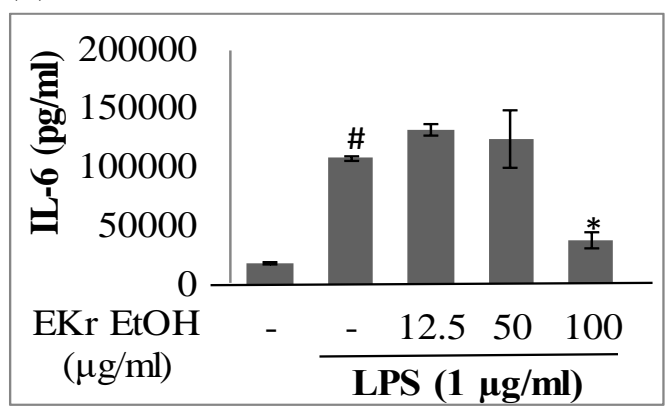

(D)

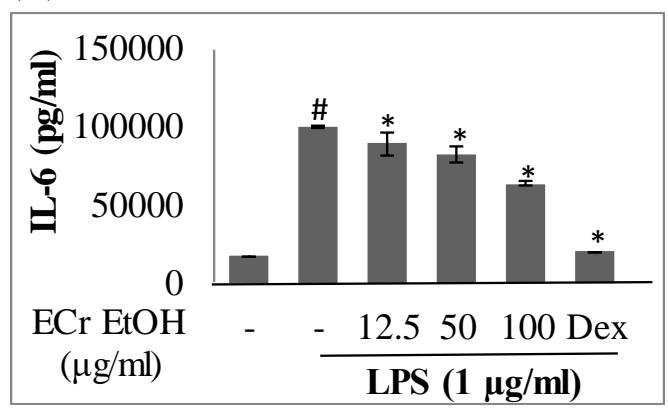

Figure 3. Effect of E. kotschyi extracts [aerial EtOH (A), root EtOH (B), aerial $\mathrm{dH}_{2} \mathrm{O}(\mathrm{C})$ ] and E. campestre var. virens root EtOH extract (D) on the IL-6 productions of LPS induced Raw 264.7 macrophages. IL-6 concentrations were determined by ELISA. Cells were co-incubated with the indicated concentrations of extracts and LPS $(1 \mu \mathrm{g} / \mathrm{ml})$ for $24 \mathrm{~h}$. Dexamethasone (Dex) was applied at $10 \mu \mathrm{M}$ concentration. (-): Only media treated control group. Error bars represent the mean \pm SEM. Values of ${ }^{*} p \leq 0.05,{ }^{* *} p \leq 0.01$ and ${ }^{* * *} p$ $\leq 0.001$ vs. LPS treated control group and \# $\mathrm{p} \leq 0.05$, \# \# $\mathrm{p} \leq 0.01$ and \# \# \# $\mathrm{p} \leq 0.001$ vs. only media treated group were considered statistically significant. 
(A)

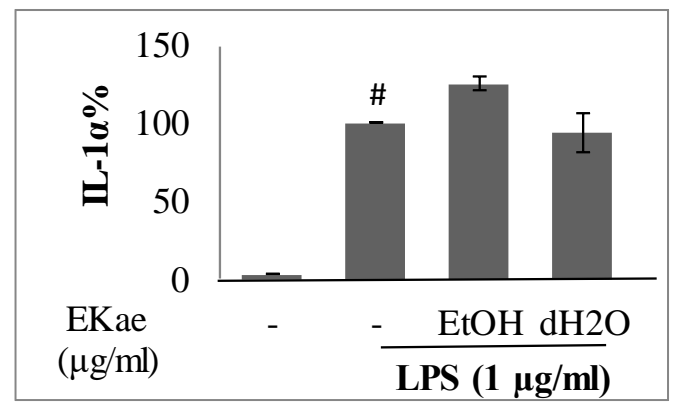

(B)

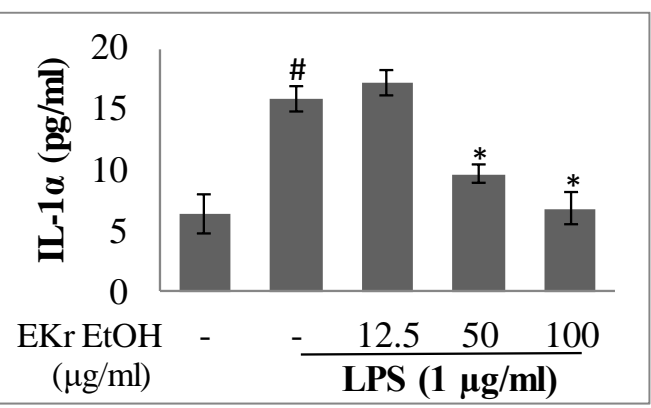

(C)

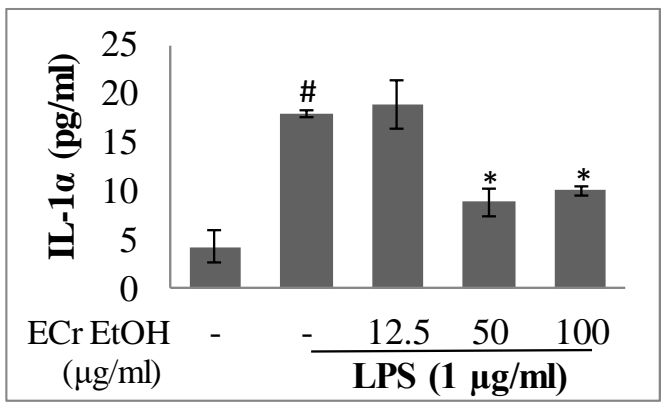

Figure 4. Effect of E. kotschyi extracts [aerial EtOH (A), root EtOH (B), aerial $\mathrm{dH}_{2} \mathrm{O}(\mathrm{A})$ ] and E. campestre var. virens root EtOH extract (C) on the IL-1a productions of LPS induced Raw 264.7 macrophages. IL-1a levels were determined by ELISA. Cells were treated with the indicated concentrations of extracts and LPS (1 $\mu \mathrm{g} / \mathrm{ml}$ ) for $24 \mathrm{~h}$. (-): Only media treated control group. Error bars represents the mean $\pm S E M$ values. Values of * $p \leq 0.05$, ${ }^{* *} p \leq 0.01$ and ${ }^{* * *} p \leq 0.001$ vs. LPS treated control group and \# $p \leq 0.05$, \#\# $p \leq 0.01$ and \# \# \# $p$ $\leq 0.001$ vs. only media treated group were considered statistically significant.

\subsection{DPPH· radical scavenging activity}

The highest $\mathrm{DPPH} \cdot$ radical scavenging activity is detected for $\mathrm{EKr} \mathrm{EtOH}$, followed by EKae $\mathrm{dH}_{2} \mathrm{O}$, EKae $\mathrm{EtOH}$ and $\mathrm{ECr} \mathrm{EtOH}$ (Table 1). The $\mathrm{IC}_{50}$ values are $1.132 \pm 0.057,1.222 \pm 0.05,2.327 \pm 0.075,2.84 \pm 0.19 \mathrm{mg} / \mathrm{ml}$ respectively. The free radical scavenging activities of the extracts were found to be lower than BHT $(0.15 \pm 0.026$ $\mathrm{mg} / \mathrm{ml}$ ). A linear relationship was not observed between $\mathrm{DPPH}{ }^{\bullet}$ radical scavenging activity and the amount of total phenolic contents.

Table 1. The antioxidant and urease inhibitory activities of plant extracts.

\begin{tabular}{|c|c|c|c|c|c|c|c|}
\hline Samples & $\begin{array}{l}\text { Extract } \\
\text { Yield } \\
(\%)\end{array}$ & $\begin{array}{c}\text { DPPH• } \\
\left(\mathrm{IC}_{50}, \mathrm{mg} / \mathrm{ml}\right)\end{array}$ & $\begin{array}{c}\text { ABTS }^{*+} \\
(\mu \mathrm{M} \\
\text { trolox/mg } \\
\text { extract) }\end{array}$ & $\begin{array}{c}\text { FRAP } \\
\left(\mathrm{mM} \mathrm{Fe}^{2+} /\right. \\
\mathrm{mg} \text { extract })^{\text {a }}\end{array}$ & $\begin{array}{l}\text { CUPRAC } \\
\text { (mM } \\
\text { trolox/mg } \\
\text { extract) }\end{array}$ & $\begin{array}{c}\text { Total } \\
\text { phenolics } \\
\text { (mg GAE/ } \\
\text { g extract) }\end{array}$ & $\begin{array}{c}\text { Urease } \\
\text { inhibition } \\
(\%) \\
(12.5 \mu \mathrm{g} / \mathrm{ml})\end{array}$ \\
\hline EKae $\mathrm{dH}_{2} \mathrm{O}$ & 12.00 & $1.222 \pm 0.05^{\mathrm{a}}$ & $2.3 \pm 0.0001^{\mathrm{a}}$ & $0.22 \pm 0.003^{a}$ & $0.66 \pm 0.01^{\mathrm{a}}$ & $3.4 \pm 0.002^{\mathrm{a}}$ & - \\
\hline EKae EtOH & 5.60 & $2.327 \pm 0.075^{b}$ & $2.4 \pm 0.0005^{a, b}$ & $0.31 \pm 0.003^{b}$ & $0.97 \pm 0.07^{b}$ & $6.1 \pm 0.001^{b}$ & - \\
\hline ECr EtOH & 6.80 & $2.84 \pm 0.19 c$ & $1.2 \pm 0.0002^{c}$ & $0.36 \pm 0.005^{c}$ & $0.51 \pm 0.009$ c & $0.2 \pm 0.05^{c}$ & $3.06 \pm 0.07^{b}$ \\
\hline EKr EtOH & 13.80 & $1.132 \pm 0.057^{\mathrm{d}}$ & $2.3 \pm 0.002^{a, b, d}$ & $0.24 \pm 0.006^{\mathrm{a}, \mathrm{d}}$ & $0.80 \pm 0.06^{\mathrm{d}}$ & $3.1 \pm 0.004^{\mathrm{d}}$ & $10.04 \pm 0.1^{\mathrm{a}}$ \\
\hline BHT & & $0.15 \pm 0.026^{\mathrm{e}}$ & $13 \pm 0.001^{\mathrm{e}}$ & $1.1 \pm 0.12^{\mathrm{e}}$ & $5.78 \pm 0.07 \mathrm{e}$ & & \\
\hline Thiourea & & & & & & & $86.17 \pm 1.2^{c}$ \\
\hline
\end{tabular}

Values are mean of triplicate determination $(n=3) \pm$ standard deviation; means with different superscripts (a-e) are significantly different, $p<0.05$, GAE-Gallic acid equivalents.

\section{6. $\mathrm{ABTS}^{\cdot+}$ radical cation scavenging activity}

As shown in Table $1, \mathrm{ABTS}^{\bullet+}$ radical scavenging activities of the extracts were as follows the EKae EtOH, EKae $\mathrm{dH}_{2} \mathrm{O}, \mathrm{EKr} \mathrm{EtOH}, \mathrm{ECr} \mathrm{EtOH}$. The values were $2.4 \pm 0.0005,2.3 \pm 0.0001,2.3 \pm 0.002$ and $1.2 \pm 0.0002 \mu \mathrm{M}$ trolox/mg extract, respectively. The free radical scavenging activities of both extracts was found to be less 
than BHT $\left(13 \pm 0.0001 \mu \mathrm{M}\right.$ trolox/mg). A linear relationship was observed between ABTS ${ }^{++}$radical scavenging activity and the amount of total phenolic contents.

\subsection{Ferric reducing antioxidant/power capacity}

As shown in Table 1, ECr EtOH $(0.36 \pm 0.005 \mathrm{mM} \mathrm{Fe}+/ \mathrm{mg}$ extract $)$ exhibited the highest ferric reducing antioxidant capacity followed by EKae EtOH $(0.31 \pm 0.003 \mathrm{mM} \mathrm{Fe} 2+/ \mathrm{mg}$ extract), EKr EtOH $(0.24 \pm 0.006 \mathrm{mM}$ $\mathrm{Fe} 2+/ \mathrm{mg}$ extract $)$ and $\mathrm{EKae} \mathrm{dH}_{2} \mathrm{O}(0.22 \pm 0.003 \mathrm{mM} \mathrm{Fe} 2+/ \mathrm{mg}$ extract). The activities of the extracts were less than BHT. A linear relationship was not observed between ferric reducing antioxidant capacity and the amount of total phenolic contents.

\subsection{Cupric ion reducing antioxidant capacity}

The cupric reducing antioxidant capacity of the extracts were as follows EKae EtOH $(0.97 \pm 0.07 \mathrm{mM}$

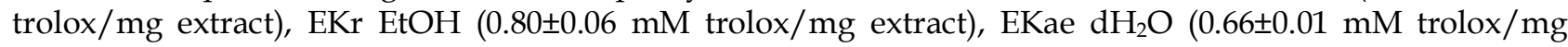
extract) and $\mathrm{ECr} \mathrm{EtOH}(0.51 \pm 0.009 \mathrm{mM}$ trolox $/ \mathrm{mg}$ extract). A linear relationship was observed between cupric reducing antioxidant capacity and the amount of total phenolic contents.

\subsection{Urease inhibitory activity}

The urease inhibitory activities of the extracts were tested at $12.5 \mu \mathrm{g} / \mathrm{ml}$ concentration. EKr EtOH exerted $10.04 \pm 0.1 \%$ inhibition of urease activity. On the other hand, $\mathrm{ECr} \mathrm{EtOH}$ showed $3.06 \pm 0.07 \%$ inhibition. Both extracts exerted lower activity than thiourea, a reference compound, which provided $86.17 \pm 1.2 \%$ inhibition at the same concentration. While the $\mathrm{dH}_{2} \mathrm{O}$ and EtOH extracts of the aerial parts of E. kotschyi did not exert significant urease inhibition (Table 1).

\section{DISCUSSION}

Despite the common traditional usage of Eryngium species for a wide spectrum of diseases in Anatolia, a literature survey revealed that, only a limited number of scientific studies have been carried out so far particularly on E. kotschyi, which is one of the endemic species to Turkish flora $[2,4,5]$. The in vivo antiinflammatory and anti-nociceptive activities of E. kotschyi and E. campestre were previosly reported [2; 29]. From the $\mathrm{MeOH}$ extract of the roots of $E$. kotschyi, bioactivity guided fractionation procedures led to the identification several active fractions and a moderate effective triterpen saponin [29]. In a previous study Kupeli et al. evaluated the in vivo anti-inflammatory activities of the aerial and root parts of various Eryngium species and reported that $\mathrm{dH}_{2} \mathrm{O}$ and $\mathrm{EtOH}$ extracts of the aerial parts of E. kotschyi as well as the EtOH extract of the root parts of E. kotschyi exerted significant in vivo anti-inflammatory activities [3]. In order to cast light onto the anti-inflammatory activity mechanism of these extracts, the present study investigated the in vitro effects of the extracts on NO, IL-6 and IL-1a production on LPS induced Raw 264.7 macrophages. EKae EtOH which was determined to be the richest extracts of phenolics, significantly inhibited NO production of LPS induced Raw 264.7 cells, but did not exert significant inhibition on IL-6 and IL-1a levels. On the other hand, EKae $\mathrm{dH}_{2} \mathrm{O}$ which is the second richest extract in phenolics, failed to inhibit NO production, but slightly reduced IL-6 levels. It's noteworthy that the aerial parts of of E. kotschyi did not exert high anti-inflammatory activity on the tested parameters except that the $\mathrm{EtOH}$ extract of the aerial parts exerted signifacant NO inhibitory activity. In the present study the roots of E. kotschyi were also investigated along with the roots of E. campestre var. virens. EtOH extracts of both plants exerted significant inhibitory activity on IL-1a productions. Although the $\mathrm{ECr} \mathrm{EtOH}$ did not effect $\mathrm{NO}$ production, $\mathrm{EKr} \mathrm{EtOH}$ significantly inhibited NO productions. ECr EtOH which contains the lowest levels of phenolics, significantly inhibited IL-6 production. The EtOH extract of the roots of E. campestre var. virens only exerted inhibitory activities on cytokine secrection. The EtOH extract of the roots of E. kotschyi exerted inhibitory activity on all parameters and it was the most active one against NO. Compared to aerial parts the roots parts of both plants exerted higher activities on all parameters except the EtOH extract of the aerial parts of E. kotschyi which exerted significant NO inhibitory activity. Literature survey revealed there is only a limited number of studies on the in vitro anti-inflammatory effects of the plants particularly against the activated macrophages. In a previous study, the EtOH extract from the aerial parts of E. campestre significantly inhibited NO secretion of cytokine stimulated murine brain endothelial cells and LPS induced murine monocyte/macrophage-like cell line P388D1 [10].

The extracts prepared from the aerial and root parts of E. kotschyi and the roots of E. campestre var. virens were also compared by means of their antioxidant activities and total phenolic contents. EKae EtOH having the richest phenolics content exerted the highest antioxidant activity by ABTS ${ }^{*+}$ and CUPRAC assays. On the 
other hand, $\mathrm{EKr} \mathrm{EtOH}$ and EKae $\mathrm{dH}_{2} \mathrm{O}$ exerted the highest antioxidant potential on DPPH• assay. ECr EtOH showed weak antioxidant potential on all assays except FRAP assay, although possessing the least phenolic content among all. In a recent study, the $\mathrm{MeOH}$ extract and subextracts obtained from the $\mathrm{MeOH}$ extract (ethyl acetate, $n$-butanol and water) of the flowering aerial parts of E. kotschyi was investigated for their total phenolic and total flavonoid compounds as well as their antioxidant capacity (DPPH•, ABTS $\bullet$ and FRAP methods). In this study, the highest total phenolic and total flavonoid content was found in ethyl acetate subextract which also showed the highest antioxidant capacity [30]. In a previous study, the boiling water extracts of the aerial parts and roots of E. kotschyi were investigated for their antioxidant potentials by DPPH $\cdot$ radical scavenging assay, phosphomolybdenum assay and reducing power assays. The boiling water extract of $E$. kotschyi aerial and root parts exerted high antioxidant capacity with $\mathrm{IC}_{50}$ values $39.38 \mu \mathrm{g} / \mathrm{ml}$ and $39.42 \mu \mathrm{g} / \mathrm{ml}$ by DPPH radical scavenging assay, and $50.90 \%$ and $49.62 \%$ as equivalent to a-tocopherol (mg/g) by phosphomolybdenum assay. Reducing power analysis verified the antioxidant capacity [31]. In the present study, the $\mathrm{dH}_{2} \mathrm{O}$ extract prepared at room temperature from the aerial parts of $E$. kotschyi was also found to exert DPPH $\cdot$ activity $\left(\mathrm{IC}_{50}=1.222 \pm 0.05 \mathrm{mg} / \mathrm{ml}\right)$. Difference with the results might be due to the differences between the extraction techniques. The DPPH • method better responds to polar compounds in the extract. The increasing temperature for the extraction procedure seems to increase the DPPH ${ }^{*}$ activity of the extract. Our results suggest that E. kotschyi aerial parts is a potential candidate for further investigations in antiinflammatory activity as well as its promising antioxidant activity.

The antioxidant activity of the aerial parts of E. campestre was reported in a number of studies [32, 33, $34,35,36,37]$. However only a few studies reported the antioxidant activity of its roots. Different solvent extracts (ethyl acetate, $n$-butanol and aqueous extracts) prepared from roots of $E$. campstre was reported to exert good antioxidant activities due to its polyphenolic compounds [33]. The $\mathrm{MeOH}$ extract of the roots was also evaluated by an antioxidant activity assay based on the Briggs-Rauscher (BR) reaction as well as TEAC and $\mathrm{DPPH}^{\bullet}$ assays and $\mathrm{IC}_{50}$ value for $\mathrm{DPPH}^{\bullet}$ assay was estimated as $216.0 \pm 4.0 \mu \mathrm{g} / \mathrm{ml}$ [38].

The urease inhibitory activites of the extracts were also evaluated as a measure to investigate antiHelicobacter pylori activities of the extracts. Only EKr EtOH exerted 10.04\% urease inhibition. The remaining extracts were not active at $12.5 \mu \mathrm{g} / \mathrm{ml}$ concentration. All extracts exerted lower activity than Thiourea.

\section{CONCLUSION}

It's revealed that the $\mathrm{EtOH}$ extracts of the root parts of $E$. kotschyi and E. campestre var. virens exerted the highest inhibitory activities on NO, IL-6 and IL-1 a productions. Containing relatively lower levels of phenolic compounds, these extracts also exerted the highest antioxidant activities on DPPH ${ }^{\cdot}$ and FRAP assays, respectively. Further investigations are needed to explain the chemical composition of these extracts to explain the observed activity. The extracts prepared from the aerial parts of E. kotschyi $\left(\mathrm{EtOH}\right.$ and $\left.\mathrm{dH}_{2} \mathrm{O}\right)$ exerted high antioxidant activities on ABTS•+, FRAP and CUPRAC assays, and on DPPH $•$ and ABTS•+ assays, respectively. These extracts were also determined to contain the highest levels of total phenolics that may contribute to explain the antioxidant activity of these extracts. On the other hand, the EtOH extracts of the aerial part of $E$. kotschyi exerted significant inhibitory activity on $\mathrm{NO}$ production.

Consequently, the results of this paper might shed light on the effects of the extracts on inflammatory mediators which might account for the previously reported in vivo anti-inflammatory activity of the E. kotschyi extracts. Besides the inhibitory activities of the extracts on $\mathrm{NO}$ and cytokines, the antioxidant activity of the extracts might contribute to the anti-inflammatory activity of the extracts. The total phenolic contents of the extracts were also reported. As far as we know this is the first report on the in vitro anti-inflammatory and urease inhibitory activities of E. kotschyi.

\section{MATERIALS AND METHODS}

\subsection{Reagents and Chemicals}

LPS, dexamethasone, dimethylsulfoxide (DMSO), Griess reagent, Folin Ciocalteu's phenol reagent, 2,4,6-tripyridyl-s-triazine, gallic acid, and 2,2-diphenyl-1-picryl-hydrazyl (DPPH*) were obtained from SigmaAldrich (St. Louis, MO). Dulbecco's modified Eagle's medium (DMEM), penicillin-streptomycine solution and Fetal bovine serum (FBS) was purchased from Invitrogen/Gibco (Grans Island, NY, USA). Enzyme linked immunosorbent assay (ELISA) kits for TNFa and IL-1a were from R\&D Systems (MN, USA) and eBiosciences respectively. L-NIL was sourced from Cayman. Butylated hydroxytoluene and 2,2'-azinobis(3-ethylbenzothiazoline-6-sulfonate) were obtained from Fluka. WST-1 reagent was purchased from Roche 
Applied Science (Mannheim, Germany).Urease (lyophilized 5 U/MG EC 3.5.1.5) were sourced from Merck $\mathrm{KGaA}$. All other reagents were of analytical grade.

\subsection{Plant material}

The aerial parts and roots of E. kotschyi Boiss., Akaydın 13365 were collected from Sariveliler and the roots of E. campestre L. var. virens (Link) Weins, Akaydın 13338 were collected from Kazanc1 (Karaman-Turkey) in July, 2010. The material was identified by G.A. (one of the authors). Voucher specimen are deposited at the Herbarium of the Faculty of Education, Hacettepe University, Ankara, Turkey.

\subsection{Extraction}

Dried and powdered roots of E. kotschyi and roots of E. campestre var. virens (10 g, each) as well as aerial parts of E. kotschyi were separately extracted two times with $90 \% \mathrm{EtOH}(200 \mathrm{ml})$ at room temperature. The extracts were filtered through a filter paper. Evaporation of the solvents to dryness under reduced pressure yielded crude E. kotschyi root EtOH extract [EKr EtOH], E. campestre var. virens root EtOH extract [ECr EtOH] and E. kotschyi aerial parts EtOH extract [EKae EtOH] (Table 1). The extracts were filtered and the organic solvent was evaporated to dryness under reduced pressure $\left(40^{\circ} \mathrm{C}\right)$. On the other hand, the dried and powdered aerial parts of E. kotschyi $(10 \mathrm{~g})$ was extracted two times with $\mathrm{dH}_{2} \mathrm{O}(200 \mathrm{ml})$. The extract was filtered and lyophilized [EKae $\mathrm{dH}_{2} \mathrm{O}$ ] (Table 1) [3].

\subsection{Determination of total phenolic contents}

FCR method was used to measure the total phenolic contents. Extract $(5 \mu \mathrm{L})$ and water $(225 \mu \mathrm{L})$ was mixed in the plate. Afterwards, Folin-Ciocalteu reagent (diluted $1 / 3$ with distilled water, $5 \mu \mathrm{L}$ ) and $2 \%$ sodium carbonate solution $(15 \mu \mathrm{L})$ were added to the mixture. It was then lefted at room temperature (RT) for 2 hours. Finally the absorbance was read at $760 \mathrm{~nm}$ against the reference using a micro plate reader. The results were calculated and expressed as mg gallic acid equivalents/g extract [39].

\subsection{Cells and cell culture}

Dulbecco's modified Eagle's medium (DMEM) was supplemented with 10\% Fetal Bovine Serum (FBS), $4 \mathrm{mM}$ L-glutamin, $100 \mathrm{IU} / \mathrm{ml}$ penicillin and $100 \mu \mathrm{g} / \mathrm{ml}$ streptomycin to prepare cell culture media. The Raw 264.7 macrophages (ATCC TIB-71) were grown in the cell culture media at $37^{\circ} \mathrm{C}$ in a humidified atmosphere containing $5 \% \mathrm{CO}_{2}$.

\subsection{WST-1 assay for cell viability}

The viability of Raw 264.7 macrophages were tested by using a WST-1 assay kit (Roche Applied Sciences). This assay depends on the reducement of a tetrazolium-based salt dye to a purple colored formazan salt by metabolically active cells. Raw 264.7 cells ( 22.500 cells/well) were seeded into 96-well plates in 10\% FBS-DMEM. The cells were treated with the indicated concentrations of the extracts ranging from $12.5 \mu \mathrm{g} / \mathrm{ml}$ to $100 \mu \mathrm{g} / \mathrm{ml}$ with $1 \mu \mathrm{g} / \mathrm{ml}$ LPS, and incubated for $24 \mathrm{hrs}\left(37^{\circ} \mathrm{C}\right)$. The supernatant was then discarded and WST-1 reagent was added directly to the wells [final concentration of $5 \%(\mathrm{v} / \mathrm{v})$ ]. The cells were incubated with the reagent at $37^{\circ} \mathrm{C}$ for an additional 60 mins. Finally, absorbance was measured between $420-480 \mathrm{~nm}\left(\lambda_{\max } 450\right.$ $\mathrm{nm})$. All extracts and standards were dissolved in DMSO. They were then diluted with DMEM. The concentration of DMSO in the cell culture medium was not more than $0.1 \%(\mathrm{v} / \mathrm{v})$.

\subsection{Griess assay}

The NO inhibitory activities were evaluated by Griess assay on LPS induced Raw 264.7 macrophages. The 96-well plates were used to seed Raw 264.7 cells at a density of 22.500 cells/well, in $10 \%$ FBS-DMEM. The indicated $(12.5 \mu \mathrm{g} / \mathrm{ml}-100 \mu \mathrm{g} / \mathrm{ml})$ concentrations of the extracts with $1 \mu \mathrm{g} / \mathrm{ml}$ LPS was applied to cells for 24 hrs at $37^{\circ} \mathrm{C}$. Accumulated nitrite in the culture medium was determined by Griess Assay. For this purpose, 50 $\mu \mathrm{l}$ of cell culture medium and $50 \mu \mathrm{l}$ of $1 \%(\mathrm{w} / \mathrm{v})$ sulfanilamide in $5 \%(\mathrm{v} / \mathrm{v})$ phosphoric acid was mixed and incubated for $10 \mathrm{mins}$. After that, $50 \mu \mathrm{l}$ of $0.1 \%$ (w/v) naphtylethylenediamine- $\mathrm{HCl}$ (Promega) was added. The mixture was then incubated at room temperature for an additional 10 mins. The absorbance was measured at $550 \mathrm{~nm}$ by a microplate reader. The amount of nitrite was calculated from the serial dilution standard curve prepared from $\mathrm{NaNO}_{2}$. 


\subsection{Enzyme immunoassay for quantification of cytokines (IL-1a, IL-6)}

The cytokine inhibitory activities were evaluated by ELISA on LPS induced Raw 264.7 macrophages. The 96-well plates were used to seed Raw 264.7 cells at a density of 22.500 cells/well, in $10 \%$ FBS-DMEM. The extracts and $1 \mu \mathrm{g} / \mathrm{ml}$ LPS were together applied to cells for $24 \mathrm{hrs}\left(37^{\circ} \mathrm{C}\right)$. The inhibitory effects of extracts on the production of cytokines were determined by Sandwich ELISA method. The supernatants were harvested and tested in agreement with the manufacturer's instructions for the relevant ELISA kit.

\section{9. $\mathrm{DPPH} \cdot$ radical scavenging activity}

The free radical scavenging capacity of extracts were determined by DPPH $\bullet$ test. The DPPH ${ }^{*}$ solution $(0.1 \mathrm{mM}, 240 \mu \mathrm{L})$ was added to extracts $(10 \mu \mathrm{L})$ prepared at varying concentrations ranging from $5 \mathrm{mg} / \mathrm{ml}$ to $0.5 \mathrm{mg} / \mathrm{ml}$. The mixture was then lefted at RT for $30 \mathrm{~min}$. The absorbance was measured against the reference at $517 \mathrm{~nm}$. The results obtained from three experiments were given as $\mathrm{IC}_{50}=\mathrm{mg} / \mathrm{ml}[40]$.

\subsection{Trolox equivalent antioxidant activity}

Briefly, $50 \mu \mathrm{L}$ of each extract was taken into the plate and $50 \mu \mathrm{L}$ of water was added. Afterwards, 150 $\mu \mathrm{L}$ of ABTS ${ }^{*+}$ working solution were added to the mixture. The absorbance of the mixture was measured against the reference using a microplate reader at $734 \mathrm{~nm}$ for $6 \mathrm{~min}$. The standard curve was prepared using trolox. The results were expressed as $\mu \mathrm{M}$ trolox/mg extract [41].

\subsection{Ferric reducing/antioxidant power (FRAP) assay}

The ferric reducing ability of extracts were evaluated using the FRAP method. The FRAP reagent (10 $\mu \mathrm{L})$ and extracts $(190 \mu \mathrm{L})$ were mixed. The absorbance of the mixture was measured after 4 mins against the reference at $593 \mathrm{~nm}$. The $\mathrm{FeSO}_{4} .7 \mathrm{H}_{2} \mathrm{O}$ standard cureve was prepared and FRAP values were expressed as a $\mathrm{mM} \mathrm{Fe}^{2+} / \mathrm{mg}$ extract [42].

\subsection{Cupric reducing antioxidant capacity (CUPRAC) assay}

CUPRAC method was used to asses the antioxidant capacity. The neocuproine ethanolic solution (7.3.10-3 M, $60 \mu \mathrm{L}), \mathrm{Cu}(\mathrm{II})\left(1.10^{-2} \mathrm{M}, 60 \mu \mathrm{L}\right)$, and $1 \mathrm{M} \mathrm{NH}_{4} \mathrm{Ac}$ buffer solution $(60 \mu \mathrm{L})$ were mixed in plate. Extracts (each in $60 \mu \mathrm{L}$ ) and $\mathrm{EtOH}$ (pure, $10 \mu \mathrm{L}$ ) were added to the initial mixture to make the total volume of $250 \mu \mathrm{L}$ and it was vortexed for $10 \mathrm{~s}$. The absorbance was measured exactly after 60 mins against a reagent blank at $450 \mathrm{~nm}$. The results were reported as trolox equivalents ( $\mathrm{mM}$ trolox/mg extract) [43].

\subsection{Urease inhibitory activity}

Urease enzyme (500 $\mu \mathrm{L})$ was mixed with the working solution $(100 \mu \mathrm{L})$. The mixture was incubated in the incubator at $37^{\circ} \mathrm{C}$ for $30 \mathrm{~min}$. After that, $1100 \mu \mathrm{L}$ of urea was added and the mixture was incubated for an additional $30 \mathrm{~min}$. in the incubator $\left(37^{\circ} \mathrm{C}\right)$. The reagents; $\mathrm{R} 1(1 \%$ phenol, $0.005 \%$ sodium nitroprusside) and $\mathrm{R} 2$ $(0.5 \% \mathrm{NaOH}, 0.1 \%$ sodium hypochlorite $)$ were added to the mixture respectively. It was then incubated for 2 hrs in the incubator at $37^{\circ} \mathrm{C}$. The absorbance was read against the reference at $635 \mathrm{~nm}$ [44].

\subsection{Statistical analysis}

The data obtained from triplicate experiments were reported as mean \pm standard deviation (SD) or mean \pm standard error ofthe mean (SEM). Graphpad Prism 5 Demo or PASW Statistics were used to analyse data. The determination of the significance of the differences between means were achieved by Tukey's Multiple Comparison Test or Mann Whitney U test. The p-values less than 0.05 were considered statistically significant.

Author contributions: Concept - İ.A.B., E.Y.; Design - İ.A.B, T.T.; Supervision - E.Y.,İ.A.B., T.T., G.A.; Resource - İ.A.B., T.T.; Materials - İ.A.B., T.T., G.A., E.Y.; Data Collection and/or Processing - İ.A.B., T.T., E.A.Ş.; Analysis and/or Interpretation - İ.A.B., T.T., E.Y.; Literature Search - İ.A.B., T.T., E.A.Ş.; Writing - İ.A.B., T.T., E.Y.; Critical Reviews İ.A.B., T.T., E.A.Ş., G.A., E.Y.

Conflict of interest statement: The authors declared no conflict of interest in the manuscript.

\section{REFERENCES}

[1] Ecevit Genç G, Akalın Uruşak E, Wörz A. A New Species of Eryngium (Apiaceae) from Turkey: Eryngium babadaghensis. Turk J Bot. 2012; 36: 1-8. [CrossRef] 
[2] Davis PH. The Flora of Turkey and the East Aegean Islands Vol. 4, Edinburgh University Press, Edinburg, 1972.

[3] Küpeli E, Kartal M, Aslan S, Yesilada, E. Comparative Evaluation Of The Anti-İnflammatory And Antinociceptive Activity of Turkish Eryngium species. J Ethnopharmacol. 2006; 107: 32-37. [CrossRef]

[4] Sezik E, Yeşilada E, Tabata M, Honda G, Takaishi Y, Fujita T, Tanaka T, Takeda Y. Traditional Medicine in Turkey VIII. Folk Medicine in East Anatolia; Erzurum, Erzincan, Ağri, Kars, Igdir Provinces. Econ Bot. 1997; 51 (3): $195-211$. [CrossRef]

[5] Yesilada E, Sezik E. Part 28. A Survey On The Traditional Medicine in Turkey: Semi-Quantitative Evaluation Of The Results. In: Singh K, Govil JN, Hashmi S, Singh G. (Eds). Recent Progress in Medicinal Plants. Vol. VII. Ethnomedicine and Pharmacognosy-II. Studium Press, LLC, Houston, Texas, 2003, pp. 389-412.

[6] Aslan Erdem S, Mitaine Offer AC, Miyamoto T, Kartal M, Lacaille Dubois MA. Triterpene Saponins from Eryngium kotschyi. Phytochemistry. 2015; 110: 160-165. [CrossRef]

[7] Yurdakök B, Baydan E. Cytotoxic Effects of Eryngium kotschyi and Eryngium maritimum on Hep2, HepG2, Vero and U138 MG Cell Lines. Pharm Biol. 2013; 51 (12): 1579-1585. [CrossRef]

[8] Usta C, Yildirim AB, Turker AU. Antibacterial And Antitumour Activities Of Some Plants Grown in Turkey. Biotechnol Biotec Eq. 2014; 28 (2): 306-315. [CrossRef]

[9] Çelik A, Aydınlık N, Arslan I. Phytochemical Constituents and Inhibitory Activity towards Methicillin-Resistant Staphylococcus aureus Strains of Eryngium Species (Apiaceae). Chem Biodivers. 2011; 8: 454-459. [CrossRef]

[10] Strzelecka M, Bzowska M, Kozieł J, Szuba B, Dubiel O, Riviera Núńez D, Heinrich M, Bereta J. Anti-Inflammatory Effects of Extracts from Some Traditional Mediterranean Diet Plants. J Physiol Pharmacol. 2005; 56 (1):139-56.

[11] Kartal M, Mitaine Offer AC, Abu Asaker M, Miyamoto T, Calis I, Wagner H, Lacaille Dubois MA. Two New Triterpene Saponins from Eryngium campestre. Chem Pharm Bull. 2005; 53(10): 1318-1320. [CrossRef]

[12] Kartal M, Mitaine Offer AC, Paululat T, Abu Asaker M, Wagner H, Mirjolet JF, Guilbaud N, Lacaille-Dubois MA. Triterpene Saponins from Eryngium campestre. J Nat Prod. 2006; 69 (7):1105-8. [CrossRef]

[13] Hohmann J, Pall Z, Gunther G, Mathe I. Flavonolacyl Glycosides of the Aerial Parts of Eryngium campestre. Planta Med. 1997; 63(1):96. [CrossRef]

[14] Kartnig T, Wolf J. Flavonoids from the Aboveground Parts of Eryngium campestre. Planta Med. $1993 ; 59(3): 285$. [CrossRef]

[15] Erdelmeier CA, Sticher O. Coumarin Derivatives from Eryngium campestre. Planta Med. 1985; 51(5):407-409. [CrossRef]

[16] Sticher O, Erdelmeier C. Cumarinderivate aus den Wurzeln von Eryngium campestre. Planta Med. 1982; 45(7): 160161. [CrossRef]

[17] Feldmann M, Maini RN. TNF Defined as A Therapeutic Target for Rheumatoid Arthritis and Other Autoimmune Diseases. Nat Med. 2003; 9: 1245-1250. [CrossRef]

[18] Heller RA, Schena M, Chai A, Shalon D, Bedilion T, Gilmore J, Woolley DE, Davis RW. Discovery and Analysis of Inflammatory Disease-Related Genes Using cDNA Microarrays. P Natl A Sci USA. 1997; 94: 2150-2155. [CrossRef]

[19] Coussens LM, Werb Z. Inflammation and Cancer. Nature. 2002; 420(6917): 860-867. [CrossRef]

[20] Tsai SH, Lin-Shiau SY, Lin JK. Suppression of Nitric Oxide Synthase And The Down-Regulation of The Activation of NF-kappaB in Macrophages by Resveratrol. Br J Pharmacol. 1999; 126(3): 673-680. [CrossRef]

[21] Chen YC, Shen SC, Lee WR, Hou WC, Yang LL, Lee TJF. Inhibition of Nitric Oxide Synthase Inhibitors and Lipopolysaccharide Induced Inducible NOS And Cyclooxygenase-2 Gene Expressions By Rutin, Quercetin, And Quercetin Pentaacetate in Raw 264.7 Macrophages. J Cell Biochem. 2001; 82: 537-548. [CrossRef]

[22] Dinarello CA. Proinflammatory Cytokines. Chest. 2000; 118: 503-508. [CrossRef]

[23] Zang JM, An J. Cytokines, Inflammation and Pain. Int Anesthesiol Clin. 2009; 45 2): 27-37. [CrossRef]

[24] Gabay C. Interleukin-6 and Chronic Inflammation. Arthritis Res Ther. 2006; 6: 1-6. [CrossRef]

[25] Geronikaki AA, Gavalas AM. Antioxidants and Inflammatory Disease: Synthetic and Natural Antioxidants with Anti-inflammatory activity. Comb Chem High Throughput Screen. 2006; 9(6): 425-442. [CrossRef]

[26] Khansari N, Shakiba Y, Mahmoudi M. Chronic Inflammation and Oxidative Stress as a Major Cause Of Age-Related Diseases and Cancer. Recent Pat Inflamm Allergy Drug Discov. 2009; 3(1):73-80. [CrossRef] 
[27] McGowan CC, Cover TL, Blaser MJ. Helicobacter pylori and Gastric Acid: Biological and Therapeutic Implications. Gastroenterology. 1996; 110: 926-938. [CrossRef]

[28] Leopoldini M, Russo N, Toscano M. The Molecular Basis of Working Mechanism of Natural Polyphenolic Antioxidants. Food Chem. 2011; 125(2): 288-306.

[29] Aslan Erdem S, Arıhan O, Mitaine Offer AC, İskit AB, Kartal M, Lacaille-Dubois MA. Antinociceptive Effects of Turkish Endemic Eryngium kotschyi Boiss. Roots by Bioactivity Guided Fractionation. Rec. Nat. Prod. 2016; 10(2): 168175.

[30] Paşayeva L, Köngül Şafak E, Arıgün T, Fatullayev T, Tugay O. In vitro Antioxidant Capacity and Phytochemical Characterization of Eryngium kotschyi Boiss. J Pharm Pharmacogn Res. 2020; 8(1): 18-31.

[31] Yurdakök B, Gencay YE, Baydan E, Erdem SA, Kartal M. Antibacterial and Antioxidant Activity of Eryngium kotschyi and Eryngium maritimum. J Food Agric Environ. 2014; 12(2): 35-39. [CrossRef]

[32] Matejić JS, Stojanović-Radić ZZ, Ristić MS, Veselinović JB, Zlatković BK, Marin PD, Džamić AM. Chemical Characterization, in vitro Biological Activity Of Essential Oils And Extracts of Three Eryngium L. Species And Molecular Docking of Selected Major Compounds. J Food Sci Technol. 2018; 55(8): 2910-2925. [CrossRef]

[33] Bouzidi S, Benkiki N, Hachemi M, Haba H. Investigation of in vitro Antioxidant Activity and in vivo Antipyretic and Anti-Inflammatory Activities of Algerian Eryngium campestre L. Curr Bioact Compd. 2017; 13(4): 340-346. [CrossRef]

[34] Gunes MG, Isgor BS, Isgor YG, Shomalı Moghaddam N, Geven F, Yildırım O. The Effects of Eryngium campestre Extracts on Glutathione-S-Transferase, Glutathione Peroxidase and Catalase Enzyme Activities. Turk J Pharm Sci. 2014; 11: 339-346.

[35] Hawas UW, Abou El-Kassem LT, Awad HM, Taie HAA. Anti-Alzheimer, Antioxidant Activities and Flavonol Glycosides of Eryngium campestre L. Curr Chem Biol. 2013; 7: 188-195. [CrossRef]

[36] Sucio S, Parvu AE. Comparative Study On The Effects Of Eryngıum Sp. Extracts in An Acute Inflammation Model in Rat. Annals of the RSCB. 2012; 17(2): 86-91.

[37] The Local Food-Nutraceuticals Consortium. Understanding Local Mediterranean Diets: A Multidisciplinary Pharmacological and Ethnobotanical Approach. Pharm Res. 2005; 52: 353-366. [CrossRef]

[38] Dall'Acqua S, Cervellati R, Loi MC, Innocenti G. Evaluation of in vitro Antioxidant Properties Of Some Traditional Sardinian Medicinal Plants: Investigation of The High Antioxidant Capacity of Rubus ulmifolius. Food Chem. 2008; 106: 745-749. [CrossRef]

[39] Ozsoy N, Can A, Yanardağ R, Akev N. Antioxidant Activity of Smilax excelsa L. Leaf Extracts. Food Chem. 2008; 110(3): 571-583. [CrossRef]

[40] Fu W, Chen J, Cai Y, Lei Y, Chen L, Pei L, Zhou D, Liang X, Ruan J. Antioxidant, Free Radical Scavenging, AntiInflammatory and Hepatoprotective Potential of the Extract From Parathelypteris Nipponica (Franch. Et Sav.) Ching. J Ethnopharmacol. 2010; 130(3): 521-528. [CrossRef]

[41] Re R, Pellegrini N, Proteggente A, Pannala A, Yang M, Rice-Evans C. Antioxidant Activity Applying An Improved ABTS Radical Cation Decolorization Assay. Free Radic Biol Med. 1999; 26(9-10): 1231-1237. [CrossRef]

[42] Benzie IF, Strain JJ. The Ferric Reducing Ability of Plasma (FRAP) As a Measure Of "Antioxidant Power": The FRAP Assay. Anal Biochem. 1996; 239(1): 70-76. [CrossRef]

[43] Apak R, Güclü K, Ozyurek M, Karademir SE. Novel Total Antioxidant Capacity Index for Dietary Polyphenols And Vitamins C and E, Using Their Cupric Ion Reducing Capability in The Presence of Neocuproine: CUPRAC Method. J Agric Food Chem. 2004; 52: 7970-7981. [CrossRef]

[44] Ghous T, Akhtar K, Nasim FUH, Choudhry MA. Screening Of Selected Medicinal Plants for Urease Inhibitory Activity. BLM. 2010; 2(4): 64-69. [CrossRef] 